\title{
Activist Feminism in Turkey, Represented Through the Caricatures of Bayan Yanı Magazine
}

\author{
Seval Erkul 1*
}

Published: April 11, 2020

\begin{abstract}
In Turkey, under the governance of a conservative political party, Adalet ve Kalkınma Partisi Justice and Development Party, AKP) since 2002, religion and conservatism has been relentlessly promoted. Both government officials and their supporters have been expressed sexist and discriminatory discourses against women keenly and frequently, causing various incidents and public outcries. Bayan Yam, being the first and only women led caricature publication in Turkey, has been widely covering the gender related, socio-political issues, since its first appearance on the market, in the early days of March 2011. This article aims to explore the way in which gender related socio-political issues, whether on the part of individuals or a more collective activist engagement, are debated in this particular publication, revealing the depiction of feminist activism and tensions surrounding women's everyday experiences of gender in Turkey.
\end{abstract}

Keywords: Feminist activism, caricature, gendered politics, political cartoons, feminist comics

\section{INTRODUCTION}

In this article, I examine the representations of activist feminism in Turkey's feminist caricature magazine Bayan Yani; the magazine focuses on a gender-related, socio-political agenda and women's everyday experiences of gender inequality in Turkey. I investigate how caricatures in Bayan Yan explore and represent such issues, whether on the part of activist individuals or in a more collective activist engagement. As my analysis reveals, the magazine promotes themes of activism, awareness, contestation and solidarity on behalf of women and gender equality in the various realms of Turkish culture, and engages with contemporary national and global agendas. In doing so, the magazine also engages with women's everyday problems, triggered by issues concerning women's complex gender identities and inequality.

Under the governance of a right-wing political party, Adalet ve Kalkemma Partisi (Justice and Development Party, AKP) since 2002, conservatism and religion have been relentlessly promoted in Turkey. Both government officials and their supporters have keenly and frequently expressed controversial and discriminatory statements on gender, causing various incidents and public outcries. Therefore, domestic violence, femicide, women's labour, policies of population control over the female body and reproductive system have all been major issues of contention, occupying feminists in Turkey (Tekay, 2013). As a feminist publication, Bayan Yam magazine has been widely covering the gender-related, socio-political turmoil in Turkey, since the publication of its first issue in 2011.

In the following section, I will give a brief summary of the Bayan Yam caricature magazine and the idea behind its first appearance on the market. Then, the methodological framework, including the selection criteria of sampled themes and caricatures follows. After that, I explore the activist feminist encounters within the magazine, revolving around the gendered socio-political turmoil in Turkey. Here, I present three sub-themes: individual endeavours, 'We Can Do It!' feminism, and collectively and publicly fighting patriarchy. In conclusion, I identify areas for further research, looking through an intersectional perspective and suggesting there appears to be some degree of limitation to the diversity represented in the magazine. 


\section{BAYAN YANI: THE FIRST AND ONLY WOMEN-LED CARICATURE MAGAZINE OF TURKEY}

Bayan Yan was first launched on $8^{\text {th }}$ March 2011 by women caricaturists and writers of the Leman publication group ${ }^{1}$, and it was originally intended to be a single, special issue, dedicated to International Women's Day. However, as a result of the positive feedback from critics and readers a decision was made to continue publishing the magazine. Bayan Yant, the first and only women-led caricature magazine of Turkey, appears on the shelves on a monthly basis, targeting mostly, but not exclusively, women. The magazine is printed in colour on A3 size paper, and it generally consists of 32 or 36 pages per issue, but in special issues the number of pages increases (there are issues with 48 and 68 pages). The publication does not only consist of caricatures, there are also articles and columns as well as photographic stories, but usually two thirds of the magazine is dedicated to caricatures. The magazine's slogan is 'Women are also capable of producing humorous content, get ready gentlemen!' (CNN Türk, 2015). As is evident here, the standpoint of the magazine echoes those feminist comic theorists who disprove 'the myth of female humourlessness', 'the myth that women have no sense of humour' (Bilger, 2009: 120; also see Gray, 1994).

The magazine presents work of various caricaturists and writers, who have diverse talents and other occupations alongside creating material for the magazine. A small group of core caricaturists and writers produce content on a regular basis, and they live in different parts of Turkey, some even abroad. Feyhan Güver, one of the main contributors of the magazine, usually depicts relationships and friendship in rural life. She states that they do not have a 'boss' within the magazine but work more collectively and are free to create as they wish, exchanging emails with each other about their ideas (Güver cited in Girardot, 2017). Caricaturist Ramize Erer, winner of the Creative Courage Award at the Angoulême Comic Festival in France in 2017, and who is one of the founders of the magazine, living in Paris, creates caricatures that provide deep and powerful messages about feminism (NTV, 2017). Elif Nursad Atalay, an internationally recognised artist and painter, creates 'psychedelic drawings, mostly inspired by cats and the female body' (Toksabay, 2011). Betül Yllmaz narrates stories of modern Istanbul and its cosmopolitan, young citizens. İpek Özsüslü is known for her unique female characters with long eyelashes, and her recreations of classical Turkish movies from the 1960-1980s with a modern and humorous twist: she puts herself in the plot as the main heroine (The Nib, 2017). Raziye İçoğlu, a ceramic artist, is widely known for her humorous column Paparaziiye in the magazine, which the columnist herself claims as being a support group therapy for women in Turkey (Toksabay, 2011). Although the contributors of Bayan Yanı have different philosophies of life: 'some are more liberal, others are Kemalist or supportive of the Kurdish movement', in general they see themselves as closer to the political opposition in Turkey (Aksoy, 2017 cited in Girardot, 2017). They all have one thing in common, resistance to the rule of AKP and its perceived misogynistic discourses (Girardot, 2017). Therefore, they are aware that imprisonment is not an outlying probability for any of the team members, although none of them has faced any litigation yet from the government (Aksoy, 2017 cited in Girardot, 2017). Reuters remarks that the magazine:

confront[s] uncomfortable topics such as "honor" killings, women's rights, sex, adultery and Islam, and with occasional irreverent glances at lighter fare such as weight loss or cellulite. (Cited in Toksabay, 2011)

Bayan Yanı has a large and growing readership community with 54,600 followers on Instagram and 77,600 on Twitter (December 2019). According to Atalay, the contributors draw on and represent what they experience as women, and therefore the focus of the magazine is mainly issues around gender inequality (Toksabay, 2011). Güver (2017 cited in Girardot, 2017) states that as the topics the magazine tackle are diverse, its caricatures are given distinct bodily features and personalities: they are sometimes 'blond and curvaceous', or 'tall, thin, young or old, coming from both urban and rural backgrounds; they are veiled or unveiled, fashionable or hopelessly untrendy'. This suggests that the magazine aims to reach women from diverse backgrounds, such as social class, occupations, and ethnicities, cultural and religious beliefs, so that they can identify with the characters in the magazine, whilst utilizing humour and wider feminist discourse.

\footnotetext{
${ }^{1}$ Leman is one of Turkey's top satirical magazines (Girardot, 2017), which has been on the market since 1991. Its attitude of being independent and not publishing advertisements led the magazine to regulate alternative ways of consumption for its audiences, which also helped the magazine to expand its revenues (Yalçınkaya, 2006). By the mid-1990s, Leman began publishing various books and magazines under the name of Leman Publications, which single-handedly transformed the magazine into a minor media establishment (Yalçınkaya, 2006). Some of the caricaturists were also encouraged to launch new magazines and books under the regulations of Leman Publications (Cantek, 1997). As a result of this attitude, in 2011 Bayan Yanı magazine appeared on the market.
} 


\section{METHODOLOGY}

For this article, I analysed the images I obtained through archival research using thematic analysis, critical discourse, and visual and textual analyses.

My archival data collection took place in December 2017 at the National Library of Turkey in Ankara, where copies of all materials published in Turkey are kept. As no digital archives were available for the caricature publications, I completed my research manually by digitally scanning hard copies of the materials. Firstly, I began the content analysis with scanning through all the issues of Bayan Yam magazine (71 issues in total), since its first appearance on the market in March 2011 until the last issue of 2017. I looked specifically at the representation of feminism through caricatures. Articles and other forms of writings and visuals were excluded from my search. Next the research material was coded, and initial themes were formed from my impressions during primary scanning. These themes were then refined throughout the research process. King (2004, cited in Nowell et al., 2017: 2) suggests that thematic analysis is precisely effective for: firstly, emphasising 'similarities and differences, and generating unanticipated insights' and secondly, 'summarizing key features of a large data set', as it helps generating a clear and systematic conclusive report, by urging the researcher to adopt 'a well-structured approach to handling data'. Hence, to deal with the large amount of visual materials in the Bayan Yam magazine archive and make coherent meaning from them, the selective thematic analysis method was appropriate.

I developed my thematic analysis further by counting the number of caricatures in each theme. It is important to note that strip caricatures who narrate stories in multiple sequences are counted as one, since separating them would initiate misinterpretation. On this basis, I concluded that activist feminism, pertaining to contemporary gendered socio-political turmoil in Turkey, was the main theme of the magazine. Therefore, in this article I have chosen to focus on the caricatures that embody activist feminism within the gendered socio-political turmoil in Turkey. Subsequently, caricatures that offered richer details were selected for in-depth analyses, avoiding representations with similar features as much as possible.

Rose (2016: 23) states that it is necessary to interpret visual materials through critical thinking, because visual materials are 'always constructed through various practices, technologies and knowledges', and therefore they are never one facet. Similarly, Kress and van Leeuwen (2006) suggest that although visual communication may seem to be transparent and simple, because we are already familiar with it, it is, in fact, always coded. Visual structures are ideological and have 'a deeply important semantic dimension', as they do not merely regenerate the reality, but they generate versions of reality, 'with the interests of the social institutions within which the images are produced, circulated and read' (Kress and van Leeuwen, 2006: 47). Indeed, Rose (2016: 24-46) also suggests that there are four sites of an image which affect its meaning: 'production, the image itself, its circulation and its audiencing' and each of these sites are formed through three modalities: 'technological, compositional and social'. On the basis of these principles, my research also benefited from some further research methods, alongside my primary approaches. I have, therefore, drawn on social semiotics in my analysis at times, because it deepens my understanding of the symbolic cultural meanings in the images. In doing so, I addressed a multimodal approach by exploring the multiple dimensions of caricatures, including gestures, linguistics and spatial aspects.

\section{A FEMINIST ACTIVISM}

Activist feminism which is shaped around the contemporary gendered socio-political landscape in Turkey is the most prominent theme of Bayan Yam magazine. Since it includes a variety of communications, I have divided the themes into three sub-categories: individual endeavours, 'We Can Do It!' feminism, collectively and publicly fighting patriarchy.

\section{INDIVIDUAL ENDEAVOURS}

In this sub-category caricatures of activist feminists individually opposing the gendered socio-political discourses are analysed. On the issue of pregnancy, on 23 July 2013 an AKP supporter and conservative lawyer, Ömer Tuğrul İnançer, spoke on television indicating that it was disgraceful and not aesthetic for pregnant women to wander the streets with their big bellies (Hürriyet Daily News, 2013). Figure 1 is a caricature reacting to this statement representing a woman who is purposely doing the opposite. 


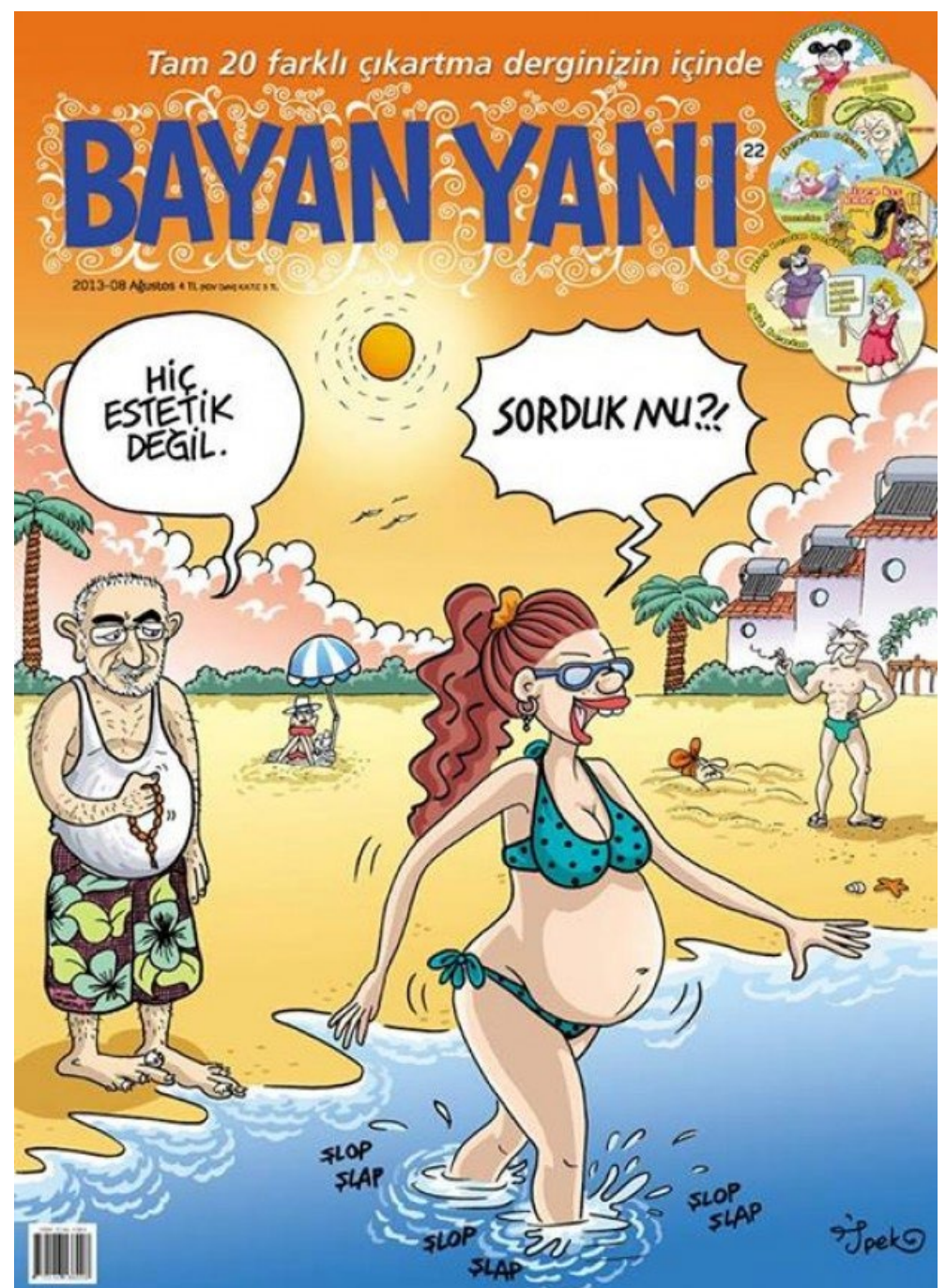

Figure 1. C İpek Özsüslü, Cover (Bayan Yan, August 2013), (Reprinted with permission). Captions:

Man: It is not aesthetic at all.

Woman: Did we ask?

The dominant colours of the caricature in Figure 1 are yellow, orange and blue, representing a summer's day in a holiday location by the sea. Providing perspective, two main figures are foregrounded and three smaller figures retreat into the background. A pregnant woman in a green, polka-dot bikini strides into the sea and an old man, in baggy floral shorts, a white sleeveless undershirt, holding prayer beads to indicate his conservative identification, looks on. He proclaims that seeing a pregnant woman, in a bikini is not aesthetic, to which the woman replies, 'Did we ask?'. Her plural expression 'we' can be interpreted as referring to the collective female identity and solidarity that the magazine promotes. In the background, three other figures are represented. A fit (muscles in evidence) younger man wearing green swimming trunks, flip-flops and smoking a cigarette stands, directing his gaze towards the pregnant woman. A second woman in a red swimsuit and hat sits under a parasol, whilst another woman's head cover can just be glimpsed, but the rest of her body is buried in sand. The latter is one of the famous rebellious characters of the magazine, who is known as Fethiye Nene (Granny Fethiye).

The most noticeable trait here is the contrasting look of the main character: a beautiful, well-groomed and stylish young woman versus an untidy, unstylish and neglected-looking, old man with cracked toenails and a hairy body. It is implied that such a man, looking as he does, is hardly placed to criticise a pregnant woman; if he can display his belly, why can't she? The woman replies wittily, looking back at him over her shoulder, paying him no attention as she continues to walk unperturbedly to the water ('slop slap, slop slap'). In a broader sense, it argues that men have no right to decide what is right or wrong for women; it is for a woman to decide what to do with her body in the public arena. A renowned feminist discourse is emphasised here: my body, my decision. However, it is also noteworthy that the pregnant woman has a flawless and slim body. As Tyler (2011: 22) states, the glorified figure of youthful mother and 'pregnant beauty' have become more visible and absurd in the public domain, with the ascending role of neoliberal celebrity culture. The elegance of pregnancy has become associated with the ability 
to achieve the 'perfect little bump', by minimising weight gain during pregnancy and has developed into a new kind of imprisonment for women (Tyler, 2011: 25). In this sense, the image can also be decoded as reproducing an idealised pregnancy beauty image, reflecting more of women's gendered oppression, imposed by popular culture.

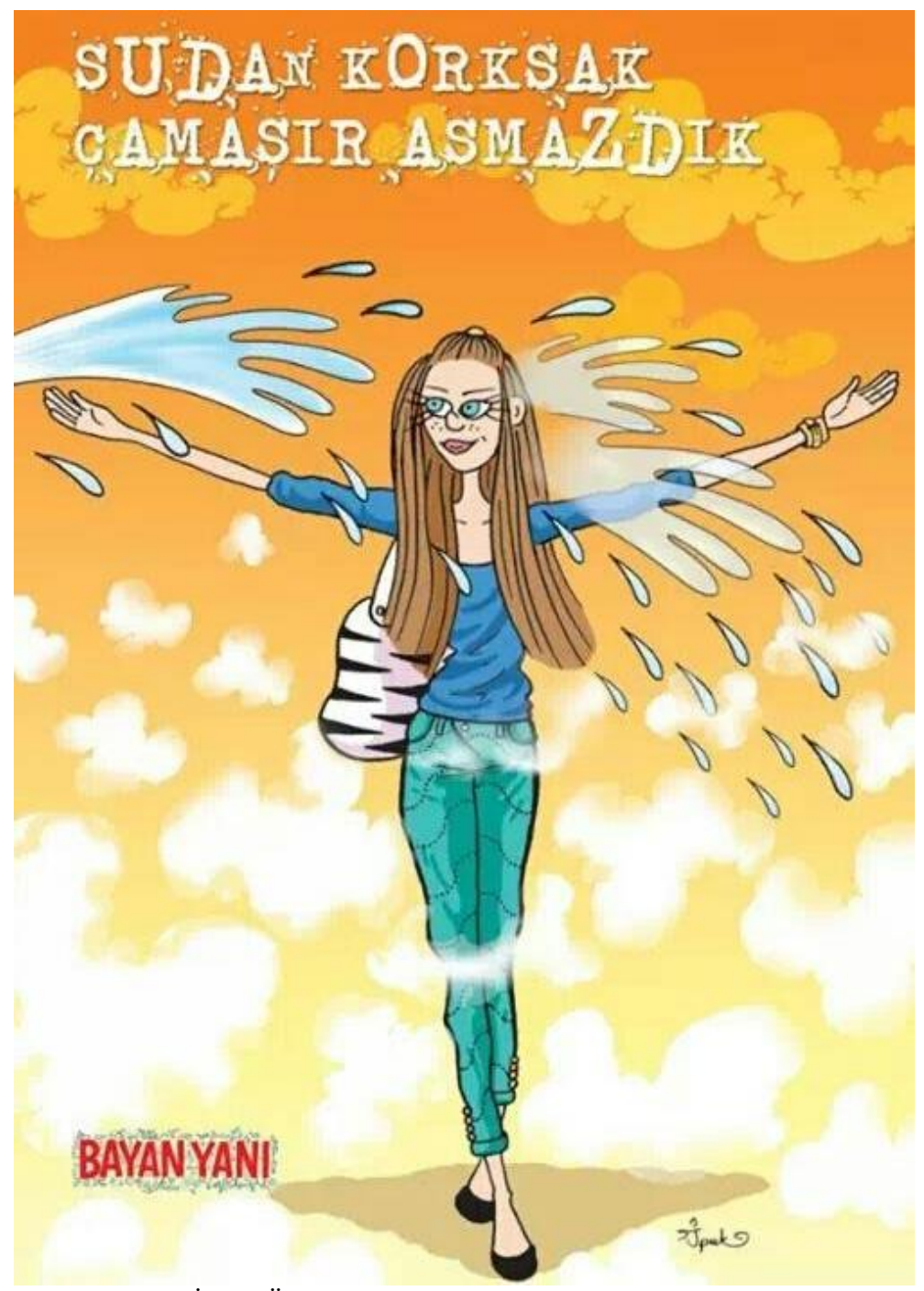

Figure 2. (C İpek Özsüslü, Inside page (Bayan Yam, July 2013), (Reprinted with permission). Caption:

If we were afraid of water, we would not be hanging out clothes.

Figures 2 and 3 relate to the Gezi Park Protests ${ }^{2}$, depicting two female protesters. The caricatures are similar to each other in terms of the meanings they produce, although they are published a year apart. Both caricatures depict the same character: a slim, light brunette woman, who is the main heroine of İpek Özsüslü's stories and is also the self-portrayal of the caricaturist. In Figure 2, the woman is depicted outdoors - clouds billow in the background and the dominant use of the yellow and orange colour connote a hot and sunny day from a social semiotics perspective. The woman character stands confidently, arms wide open, as if she is welcoming the water directed at her. This is an intertextual reference to the iconic 'woman in black' of the Gezi Park Protests, who responded similarly to the pressurised water targeted at her. In this sense, the figure in the caricature connotes a brave, determined and modern woman, empowering other women to rise-up against gender inequality.

\footnotetext{
${ }^{2}$ On 27 May 2013, a local demonstration with a few environmentalists began in Gezi Park, which is located in the heart of Istanbul, to protest its destruction. Soon after, in response to the overly aggressive intervention by police armed with water cannons and tear gas, the protest spread, and millions of people flooded not only into Gezi Park but also to other local parks and squares across the country. Afterwards, the protests became anti-governmental and people from around the world supported the protests by organizing demonstrations in their homelands and sending messages via social media (see Amnesty International, 2013; Arat, 2013; Özen, 2015).
} 


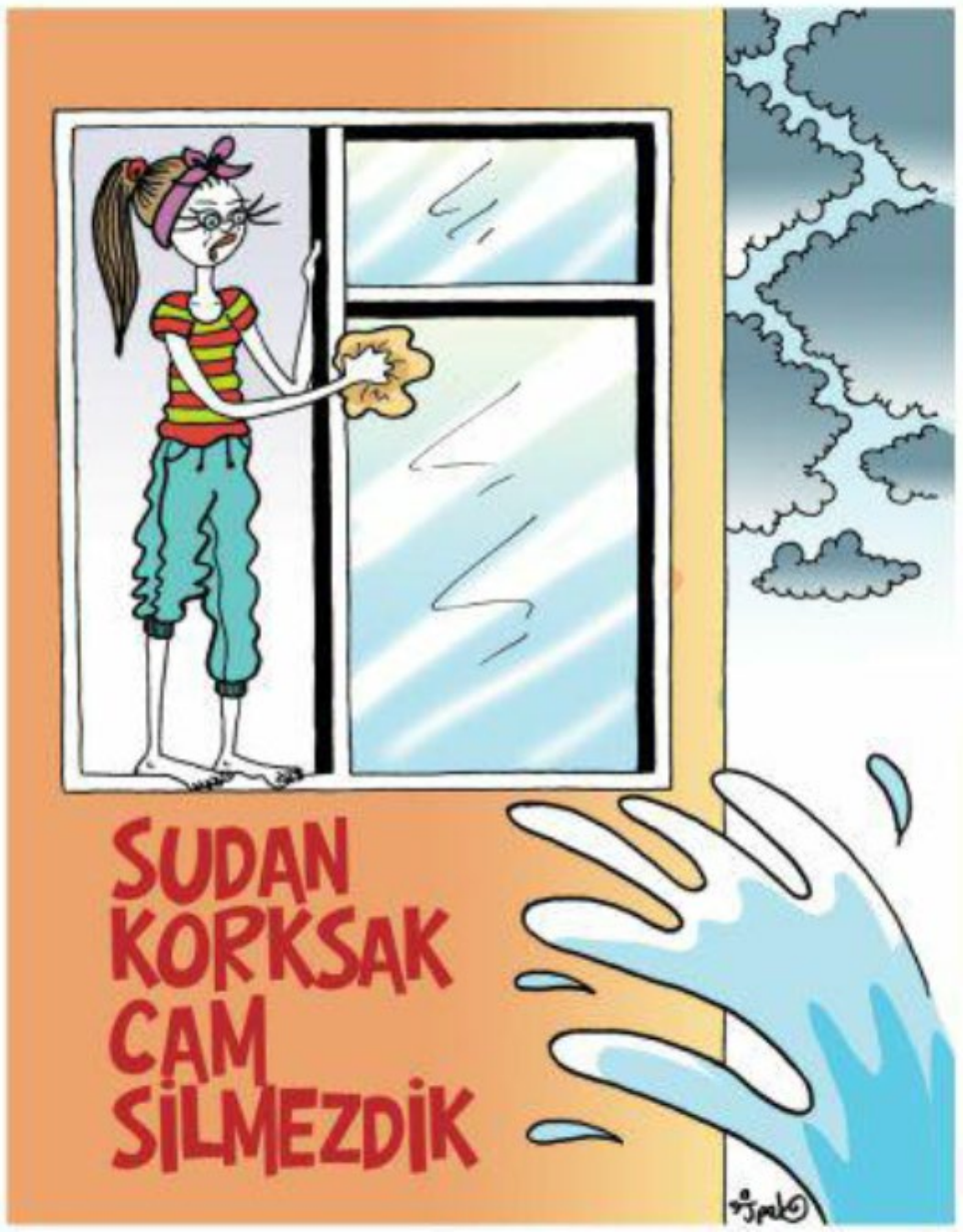

Figure 3. C İpek Özsüslü, Inside page (Bayan Yanı, June 2014), (Reprinted with permission). Caption:

If we were afraid of water, we would not be wiping windows.

In Figure 3, the woman wipes the windows by balancing on a window frame, as water from outside the frame is targeted at her. She stands fearlessly without any safety precautions (a common practise in Turkey to clean domestic windows). The captions in both images state that women are fearless in their domestic responsibilities. However, these images can be interpreted to suggest that household duties have been accepted as the responsibility of women, and on this basis, women are encouraged to be strong. Herewith, these caricatures limit women, referring to their existence in the domestic sphere with traditional roles and household responsibilities. Therefore, it can be suggested that such portrayals reproduce and normalise already existing gender norms and roles, rather than encouraging women and society as a whole to break the norm and overcome unequal labour division.

Further controversial injunctions on what women should not do were made in the General Assembly by former Deputy Prime Minister, Bülent Arınç in 2015. He warned a former female MP saying: 'Shush lady, be silent as a woman' (BIA News Desk, 29 July 2015). Taking up this issue, Figure 4 offers a harder and more violent representation: a grey-haired, black-suited and seemingly toothless man with wrinkled face (resembling Bülent Arınç), tries to silence an anonymous young, blonde woman, wearing a dark blue spotted shirt.

The background colour of the caricature is green, the traditional colour of Islam, having predominant usage in different realms of Islamic life (Akyüz, 2014) ${ }^{3}$, and here it can be read as emphasising the conservative Islamic identity of the man and the government he represents. A pin with a white crescent and star, which are the symbols of the national flag of Turkey are seen on the man's left collar, signalling the man's legislative identity. His black clothes and large black pupils, together with utter blackness in his mouth can be interpreted as embodiments of not only his, but also the government's seemingly endless oppressive attitude towards the role of women in society and gender related socio-political issues. Portraying the man as older than he is in real life can also be read as underlining the government's outdated approach on gender issues.

\footnotetext{
${ }^{3}$ The colour green is largely recognised as the colour of Islam and according to Islamic understanding it represents nature, liveliness, freshness, wealth, fertility, happiness, hope and peace. Clothing such as green robes and turbans usually worn by persons of religion and mosques and mausoleums are often coloured green (Akyüz, 2014).
} 


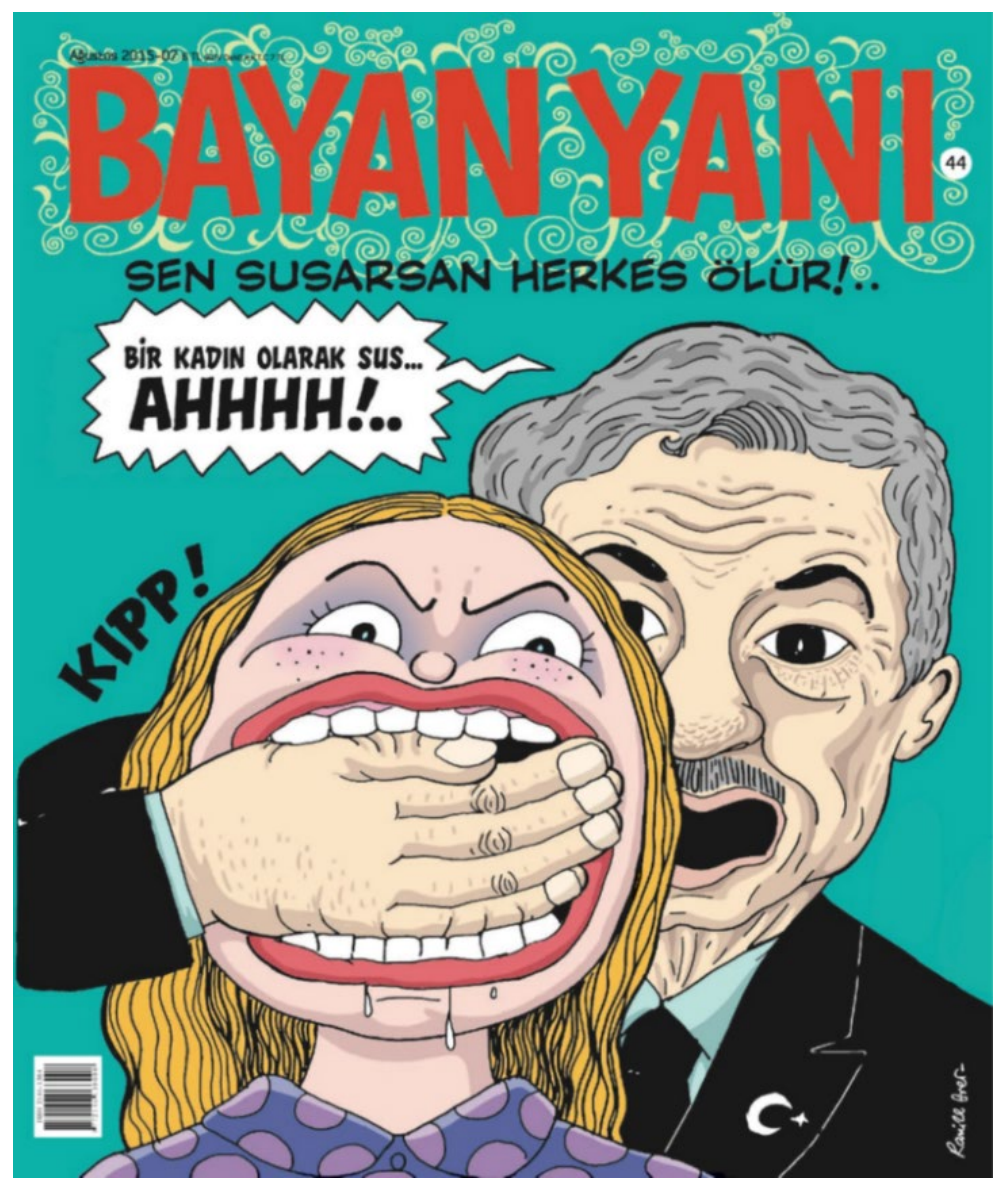

Figure 4. (C) Ramize Erer, Cover (Bayan Yam, August 2015), (Reprinted with permission). Captions:

If you keep quiet, everyone dies!..

The man: Be silent as a woman... Ahhhh!..

Furthermore, the man seals the young woman's mouth with his bare hand and is saying, 'Be silent as a woman', as Arınç said in the Assembly. In return, however, the woman in the caricature says nothing, but bites man's hand to get rid of the obstacle that tries to silence her, causing him to let out a yell. She has unusually big mouth and teeth, covering almost two thirds of her face in which the man's hand can easily fit. Her mouth is salivating as she bites man's hand. All these features give her a monstrous look as she instinctively tries to defend herself against danger. As pointed out by Creed $(1993,1999)$, the monstrous female body is a prevalent figure in many cultures, especially in myths and legends, seeming to cross borders between human and inhuman, good and evil, proper and abnormal gender roles. The monstrous representation of the female body is found in myths regarding women as castrators, what Creed entitles as 'a major archetype of female monstrosity'(1993: 105), that pushes men to confront their biggest fear of all, that is the threat of castration, by 'the vagina dentata or toothed vagina' (1999: 251; also see Walker, 1983; Harrington, 2018).

The vagina dentata is frequently symbolised with the metaphoric usage of the mouth because of the mythical and linguistic connotations concerning the mouth and women's genitals (Walker, 1983; Creed, 1993; Rees, 2013; Harrington, 2018). The mouth and the vagina, being 'powerful bodily orifice[s]', have long been associated with each other (Rees, 2013: 51), as such in many Egyptian and Greek myths (Walker, 1983). The mouth arouses 'the allure of vagina dentata' (Harrington, 2018: 61), as the damaging female characteristic usually emerges 'in the archetypal form of a mouth bristling with teeth' (Rees 2013: 222). Building on this, the monstrous depiction of the woman's mouth in Figure 4 can be read as symbolising the castrating toothed vagina. Moreover, Creed (1993) suggests that, women as castrators depict dynamic, powerful and damaging monster figures, challenging the traditional gender position of women as passive victims. This phenomenon of active female castrator is also present in this caricature, as the main heroine is actively defending herself against the man and the patriarchal order as a whole. This can also be read as female empowerment as it emphasises women's agency as having the power to confront men with their greatest subconscious fears. The captions above the figures encourage and empower women to speak up against gendered prejudices, by suggesting that keeping one's experience of abuse quiet may cause other people to be harmed as well. 


\section{'WE CAN DO IT!' FEMINISM}

The second sub-category to be investigated in detail is the 'We Can Do It!' feminism, a message that is repeated in the magazine on various occasions to empower women. The origin of the image is the iconic World War II poster from the USA, known as 'Rosie the Riveter's, which has been adopted internationally by feminists. Rosie the Riveter, as a feminist icon has been in the spotlight for feminists in Turkey, as well as mobilised by the Bayan Yam magazine.

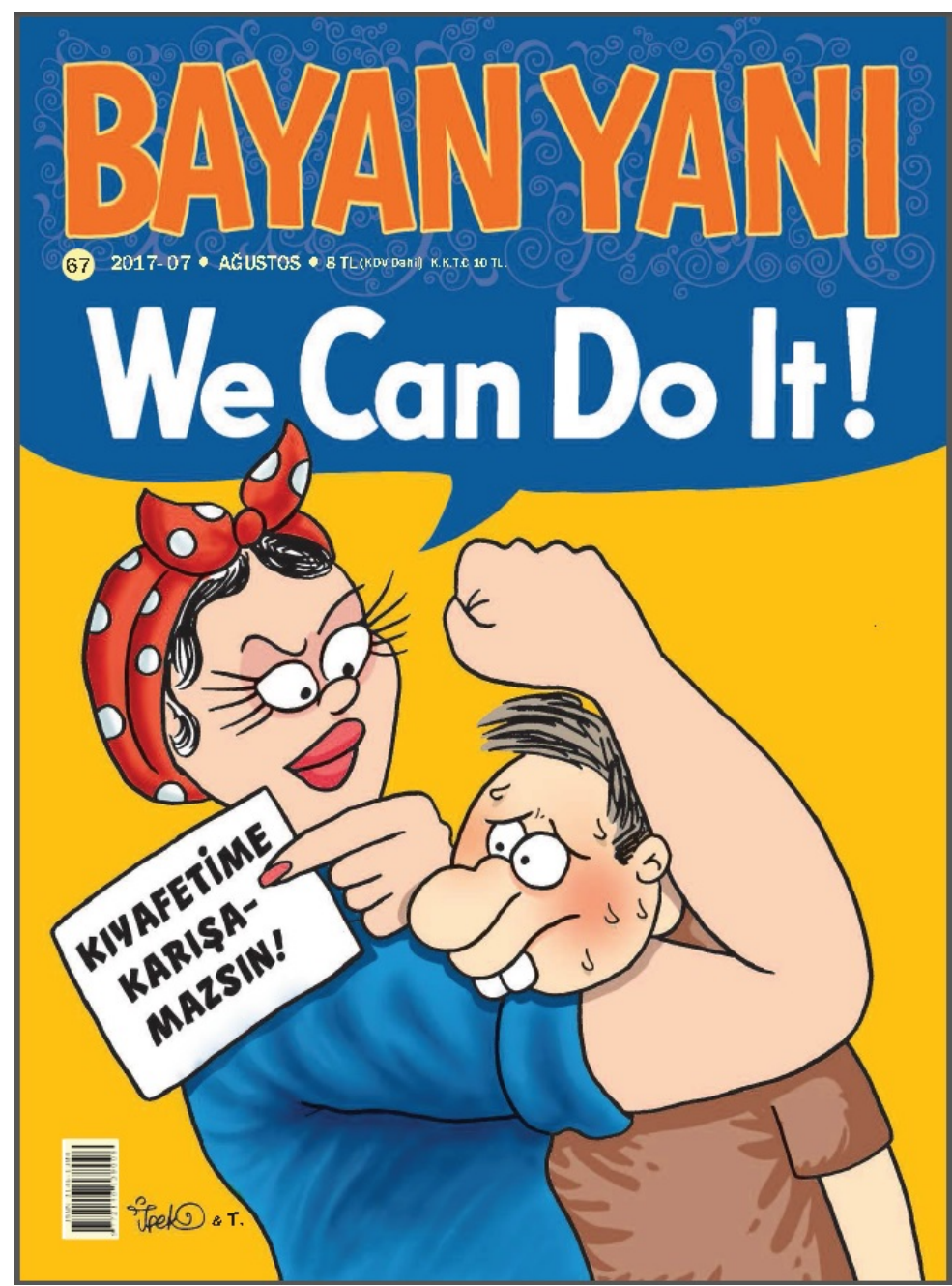

Figure 5. C İpek Özsüslü, Cover (Bayan Yanı, August 2017), (Reprinted with permission).

Caption:

My clothes are not your concern!

Figure 5 is an interpretation of the poster on the cover page of the August 2017 issue. As a whole, the caricature closely resembles the original poster (apart from an additional male character) with its prominent colours of yellowy orange and blue, representing a strong woman with the caption 'We Can Do It!'. From a social semiotics reading, the background colours evoke optimism, spaciousness and dynamism (Robinson et al., 2015). The heroine wears

\footnotetext{
${ }^{4}$ The 'We Can Do It!' poster was created by Howard Miller in 1943, containing the image of a strong woman, known as 'Rosie the Riveter'. As Kimble and Olson (2006) point out it was a propaganda poster created for Westinghouse Electric and Manufacturing Company, to encourage women to join their workforce and to motivate them to increase the productivity of their factories during World War II when men were on the front lines fighting for their country. Tobias (1997: 53) describes Rosie the Riveter as having 'movie-star looks, hair pulled up in a colorful bandanna, sleeves rolled high, ready to take rivet gun in hand', and in her newly designed workwear, 'she was cajoled into taking one of those dirty wartime jobs-out of patriotism and boredom (or both)'. However, in its initial publication the poster was far from being used as an empowerment tool for women and it had been forgotten for many years after the war (Kimble and Olson, 2006; Milkman, 1987). It was only after the 1960s with the onset of the second wave feminism movement that the Rosie the Riveter images reappeared with a new purpose to empower women rather than being a propaganda tool and the 'We Can Do It!' message was adopted by feminist groups, making Rosie an authentic feminist icon (Milkman, 1987; English, 2015).
} 
a blue top with rolled up sleeves and a red bandanna with white polka dots, which partially covers her wavy hair just like the actual Rosie the Riveter. She is well-groomed and womanly in the way that she wears make-up: red lipstick, nail polish with long and defined eyelashes. She has a very determined and strong expression on her face, as opposed to the man's worried, confused and sweaty face which is trapped by her arm. Her power is supported by her muscled right arm, which looks disproportionately big and strong compared to the rest of her body, whilst the man, shorter and with a thin arm, seems weak. The woman clutches his head and directs his gaze to the written note she is holding on her left hand in capital letters, declaring her clothes are not a man's concern. The 'We Can Do It!' message in a blue speech bubble echoes the original poster. The slogan suggests that women have the required power to change gendered oppression in society. The caricature also implies how powerless a man can be in the face of a powerful and determined woman.

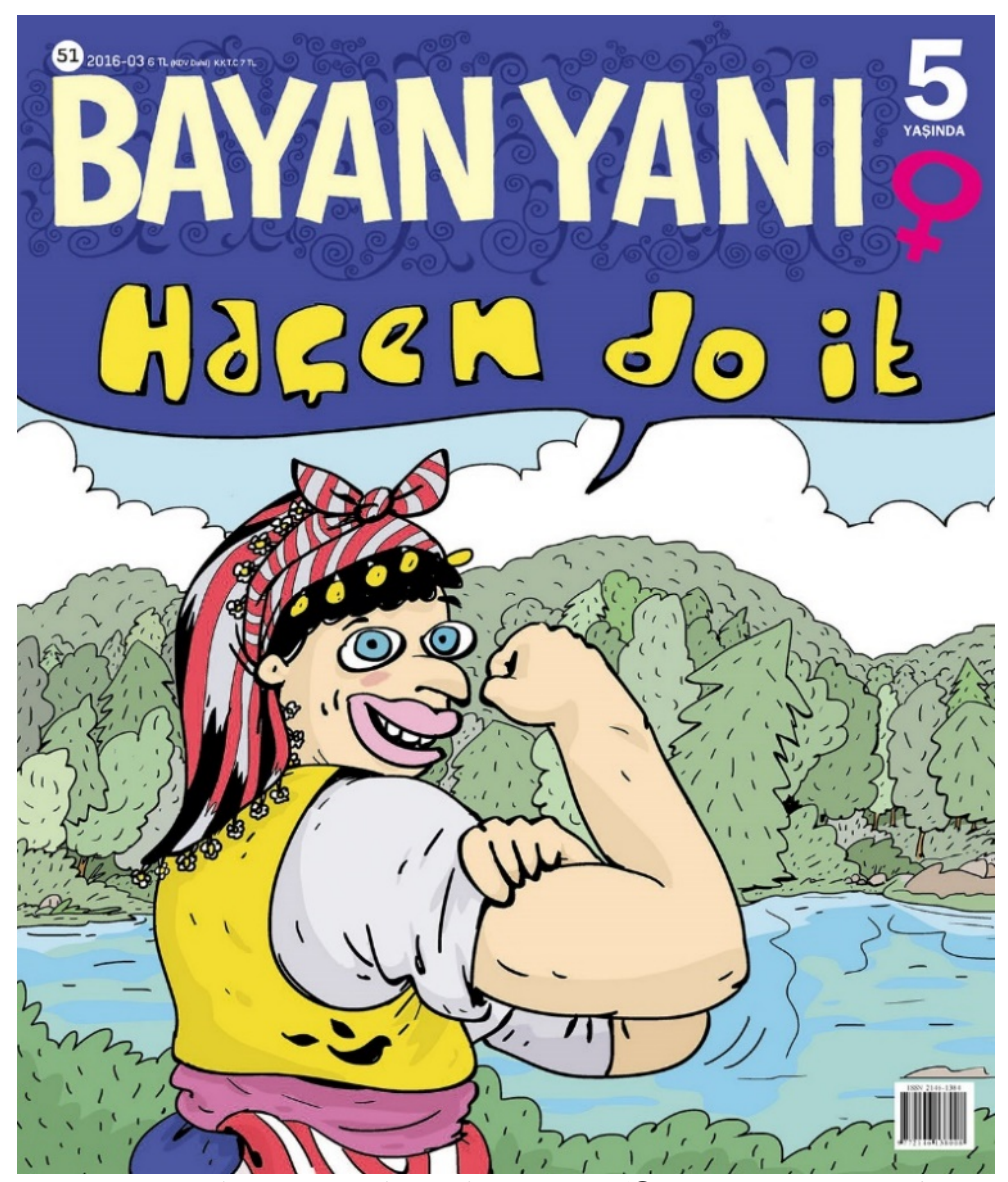

Figure 6. Unknown Caricaturist, Cover (C) Bayan Yam, March 2016), (Reprinted with permission).

Figure 6 is another interpretation of the Rosie the Riveter poster, again having some similar features with the original image, but it also has some specific micro-culturally Turkish political elements. The caricature relates to the Artvin resistance ${ }^{5}$. Therefore, the feminist icon is depicted as a traditional north eastern woman from the Black Sea region and the 'We Can Do It!' message has a touch of a local accent: 'Haçen Do It'. ('Haçen' is a word that is a product of the local Laz accent in the Black Sea region, meaning interchangeably 'hey', 'then', 'if.) The region is famous for its picturesque green fields, forests and steep hills and mountains as represented in the background of the caricature (and thus differing from the bicolored background of the original poster). The characteristic features of people living in this region are usually referred to as having pale skin, blue eyes and arched noses that are apparent on the woman in the caricature, with some exaggerations that give her a comical look. Instead of a work uniform she wears a traditional local outfit completed with a striped and embellished headcover. Her positioning is similar to the original Rosie, as she is depicted from her right side, looking over her right shoulder and raising

\footnotetext{
${ }^{5}$ Artvin is a city in the north eastern part of Turkey. For more than a quarter of a century locals in Artvin have been fighting against the use of a 250 hectare field for mining gold, copper, zinc and silver in the area of Cerattepe, which has a rich variety of fauna and flora hosting 2,000 plant forms, 124 endemic forms and hundreds of animals. Drilling works were first launched in the area in 1987 and people have been fighting actively and legally ever since. On 16 February 2016, security forces and vehicles belonging to the mining company wanted to enter the area and attacked the people who resisted them (BIA News Desk, 2016; 2019).
} 
her strong and muscular right arm to show her strength. Women of the Black Sea region are usually referred to as being strong both physically and mentally and therefore being capable of accomplishing tough tasks. In short, the caricature promotes solidarity with the people of the Black Sea region in their ongoing resistance by specifically addressing and empowering female members of the community who have been actively fighting for their environment, despite the many challenges they have faced over the years.

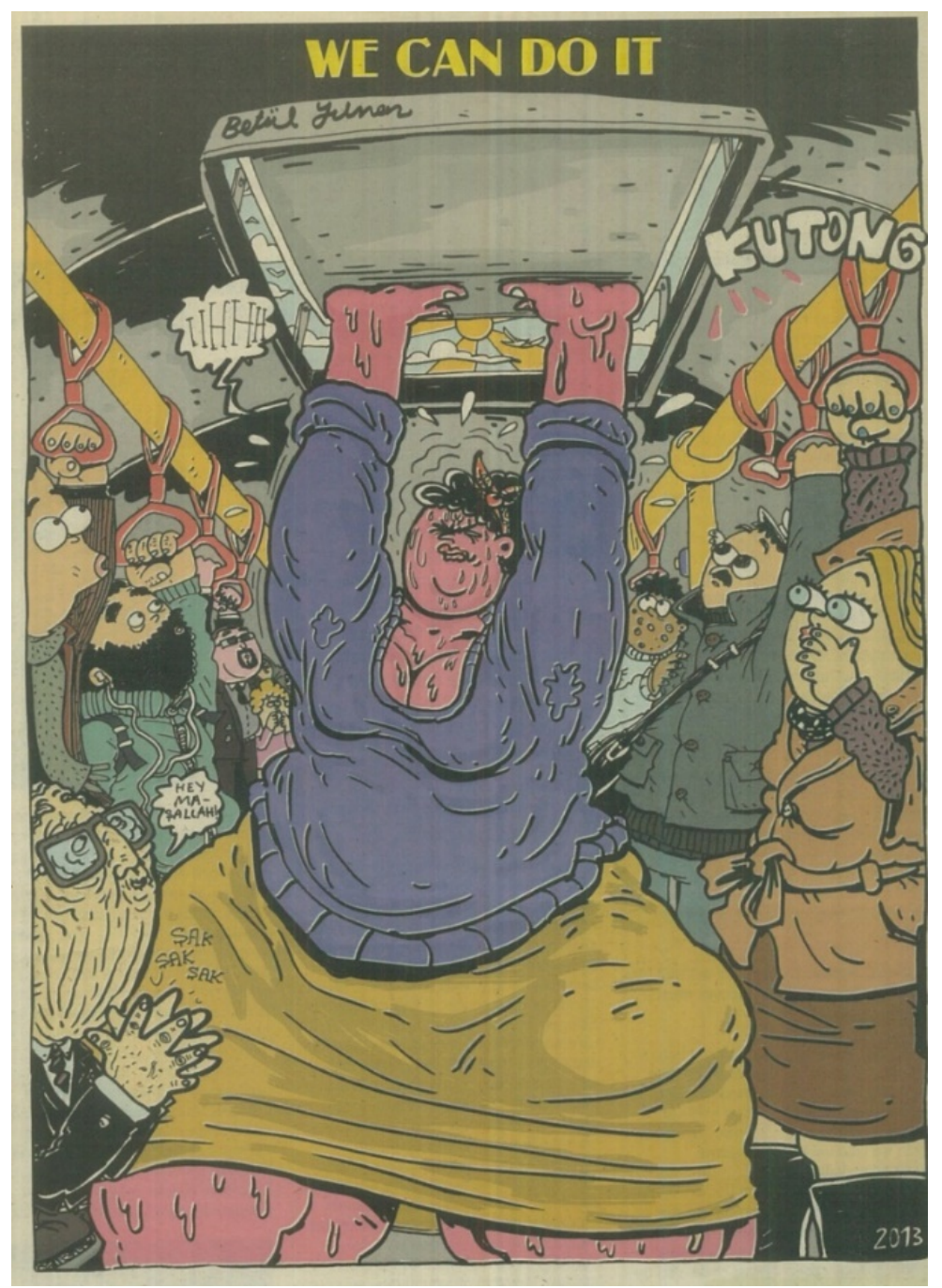

Figure 7. (C) Betül Yllmaz, Inside page (Bayan Yam, March 2013), (Reprinted with permission). Caption: The old man in the left-hand corner: How magnificent!

Differing from the first two images of the sub-category, the main heroines in Figures 7 and 8 appear to be more active, as they demonstrate a muscular strength by engaging in physical tasks. The women are huge and bulky, and it can be inferred that they are the same character, as their face and body features are quite similar. Medhurst and Desousa (1981: 214) argue that the size of an object within the frame of a caricature 'embodies valuative statements and values invite judgments'. This phenomenon can be explained by the concept, the bigger the object, the bigger its value (see Medhurst and Desousa, 1981) and it is relevant to these caricatures, as the main female figures cover most of the frame. 


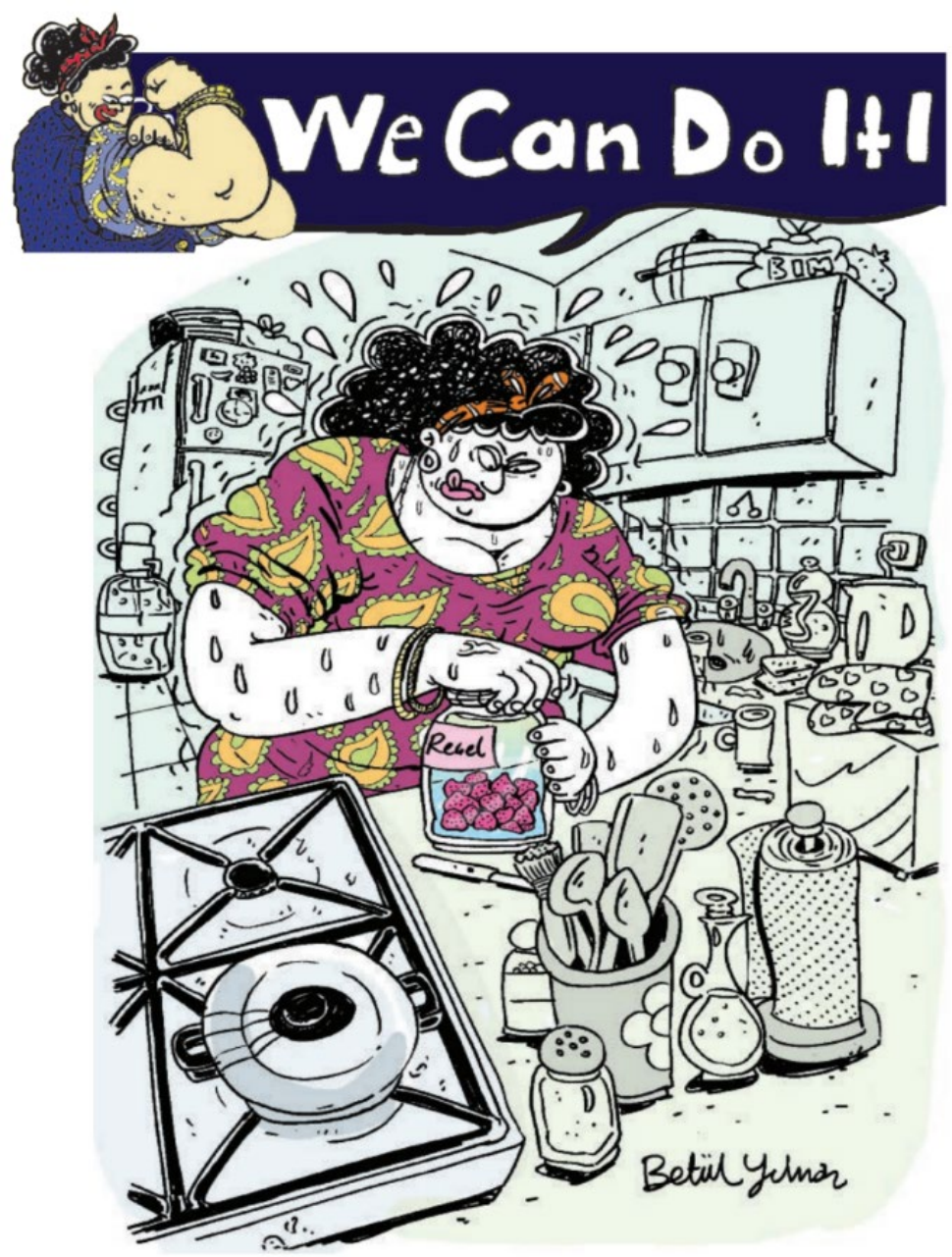

Figure 8. (C) Betül Yllmaz, Inside page (Bayan Yam, July 2015), (Reprinted with permission).

Both women are engaged in traditionally masculine activities: in Figure 7, on the left the woman opens the ventilation window on the top of a bus, using both her hands and all her strength, which is signified by sweat and a grimacing ed facial expression. The woman on the right uses her force, again signified by sweating and a strained facial expression, whilst trying to open a jam jar. By placing the caricatures in the middle of their respective frames it suggests that they are at the core of their environments, while other people or objects surround and support them (see Kress and van Leeuwen, 2006). In Figure 7 the woman wins appreciation from the other passengers (evident in the words of the old man), although some of them seem to be shocked at how strong she is. Indeed, she is represented as 'a superwoman', providing fresh air for the passengers and possibly saving them from a hazard. The second woman in Figure 8, however, is alone in a kitchen. Although she is also represented as physically strong and not needing a man to help her, the kitchen signifies another story that pertains to many other women: she is surrounded by evidence of household duties, arguably imprisoned in this private domestic sphere. Thus, the caricature reproduces representational norms, while at the same time, criticises them through a signification of empowerment.

\section{COLLECTIVELY AND PUBLICLY FIGHTING PATRIARCHY}

In this sub-category caricatures of activist feminist women who fight collectively against the gendered sociopolitical discourses are analysed. On $28^{\text {th }}$ July 2011 , a young female volleyball player was beaten by a male passenger on the bus on the grounds that she was wearing shorts. She was punched in the face, splitting her lip (Milliyet, 2011). Figure 9 is the cover page of the September 2011 issue of Bayan Yam, in support of the young girl and against the violent incident. 


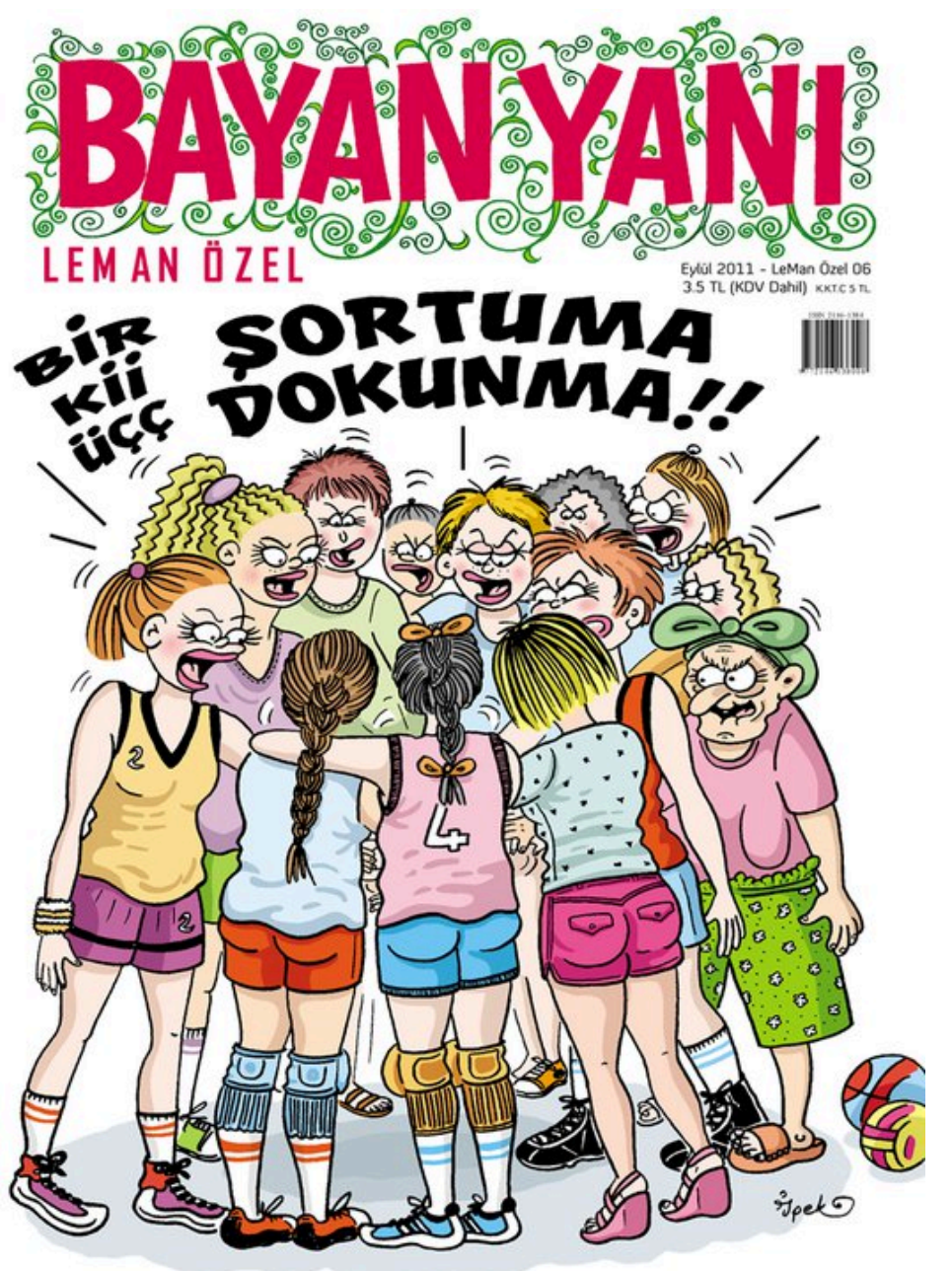

Figure 9. C İpek Özsüslü, Cover (Bayan Yam, September 2011), (Reprinted with permission). Captions:

One, two, three. Don’t touch my shorts!

The caricature of thirteen women wearing either sports shorts as part of a team uniform or casual wear to show their solidarity and sympathy with the beaten women. The background of the caricature is white, which creates a blankness that surrounds the women. White is usually perceived positively and associated with 'purity, cleanliness, and peace' in social semiotics (Mahnke, 1996 quoted in Robinson et al., 2015: 663). In this sense, the colour preferences can be read as indicating the peaceful and legitimate spirit of the women's resistance. Each woman has relatively diverse body features, being short, tall, blonde, brunette, red-headed, short haired and long haired, all of which can be interpreted as representing a diversity of women, to a certain extent. However, all of them look young and seem to have proportional bodies, apart from Granny Fethiye who is standing on the right-hand side with her unusual knotted head cover. Overall, the caricature promotes the idea that there is safety in numbers and women are free to choose what they wear, regardless of their age and body features. However, it might be argued that the portrayal of diversity is also limited: there are no overweight women or disproportioned bodies, perhaps suggesting traces of the idealised female body image. There are also no women of colour or ethnic minorities represented in the caricature.

As for Granny Fethiye, the distinct features which separate her from the others are her floppy breasts, wrinkled toothless face and unfashionable clothes. She wears open toe slippers and long, casual, floral printed shorts that look like underpants or nightwear, usually worn by older women. This gives an impression that she was sitting at home and suddenly rushed out to join the girls. As Lemish and Muhlbauer suggest, elderly people are commonly 'under-represented' and set up 'to be marginal to plot lines, to play secondary characters, and to be represented in a highly stereotypical manner' (2012: 166). Representing the 'odd' one in a group of young women, Granny Fethiye is the marginalised character here. Placed in the far right-hand corner, rather than being placed somewhere in the middle of the group, is another indication of her subordinate role. However, from a different perspective, she is not in her private space, nor in a vulnerable or helpless situation, which is quite the contrary to more usual media representations of elderly people (Lemish and Muhlbauer, 2012). In this sense, she is challenging the conventional construction of elderly people: she is outside, independent and an active supporter of women's rights. 


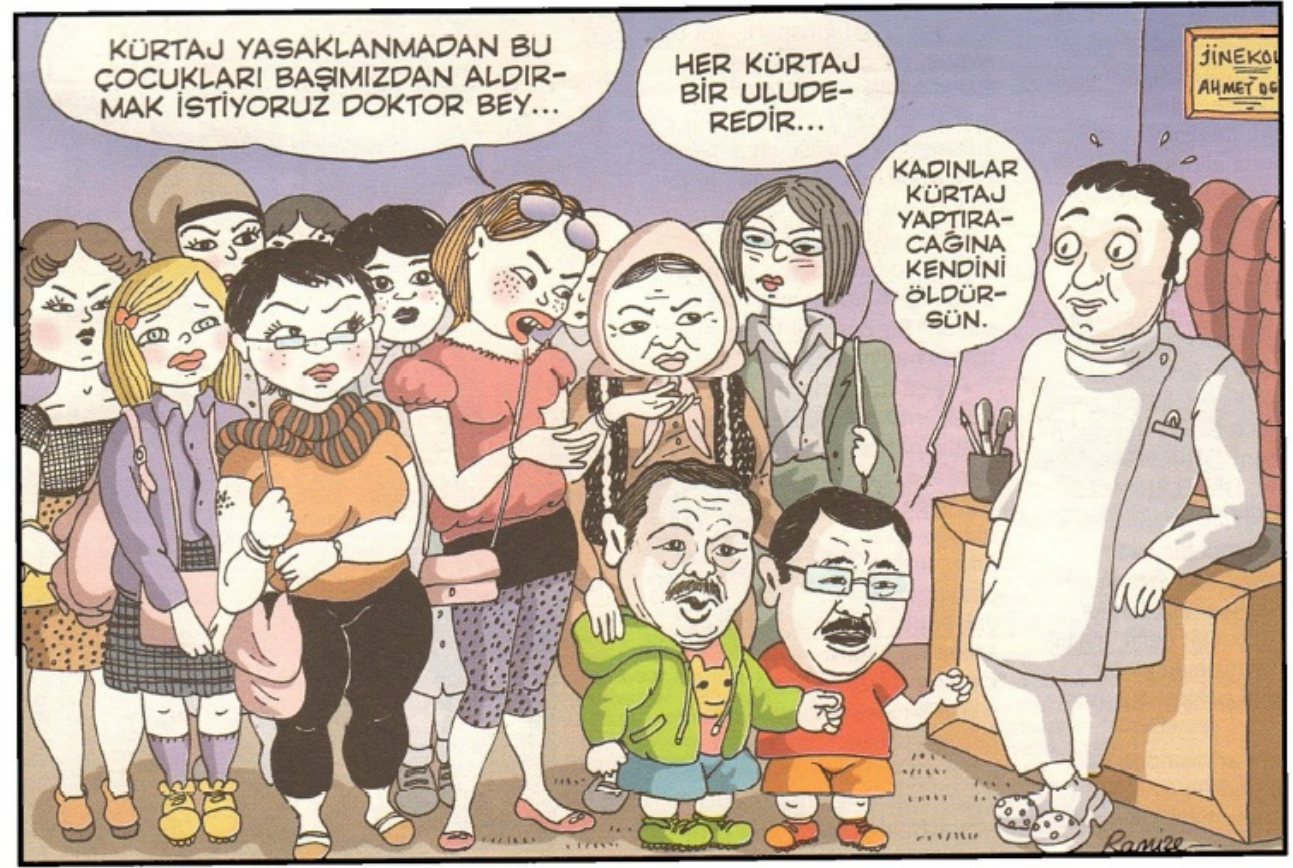

Figure 10. (C) Ramize Erer, Inside page (Bayan Yam, June 2012), (Reprinted with permission). Captions:

The woman: Before the abortion is forbidden, we want to get rid of these kids, doctor.

Little Erdoğan: Every abortion is an Uludere...

Little Gökçek: Women should kill themselves, instead of aborting their babies.

Figure 10 of the sub-theme concerns the issue of abortion. On 25 May 2012, during the United Nation's International Conference on Population and Development held in Turkey, the current Prime Minister, Recep Tayyip Erdoğan, stated that he was against abortion and caesarean births because he believed they are carried out for the sole purpose of preventing Turkey's population growth. He added that there was no difference between abortion and committing murder (Hürriyet Daily News, 2012). He went on to link abortion and the Uludere

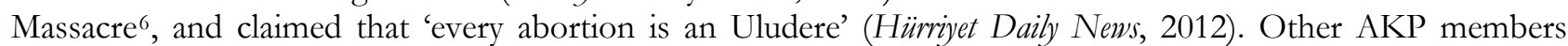
supported this idea. The former minister of health, Recep Akdağ, suggested that the government would take care of the babies of 'rape victims' rather than allow them to be aborted (Letsch, 2012). Former Metropolitan Municipality Mayor of Ankara, Melih Gökçek, stated in a TV interview that women should behave well, then there would be no need for abortion, and children would not suffer due to their mothers' misbehaviour (Letsch, 2012). He further advised that mothers should kill themselves, instead of aborting (in his view killing) their babies (Letsch, 2012).

Figure 10 demonstrates one of the many responses from Bayan Yanı to government politicians Erdoğan and Gökçek's comments. The caricature depicts a group of women visiting a gynaecologist's office. A woman in the foreground speaking on behalf of all declares: 'Before the abortion is forbidden, we want to get rid of these kids, doctor'. And the 'kids' are a child version of Erdoğan and Gökçek, who are repeating their statements (as cited above). Frowning women in this group look angry and annoyed at the two men. Only one woman (young, blonde, second from the left) wears a sad and worried facial expression. With her chequered skirt, backpack and knee-high socks, she is perhaps a student, just finishing her class and joining the others. The doctor, leaning nonchalantly against his desk, seems nevertheless to be startled by such a request: eyes wide open, eyebrows raised. As in Figure 9, each woman's bodily features are again diversely represented, as well as their styles of dress. The depiction of women in Figure 10 is more diverse than in Figure 9, as is evident in the portrayal of women with headscarves and curvaceous bodies. Three women wear headscarves with one at the back tying it like a turban, a style usually adopted by conservative women, and the others tying it more casually, allowing a piece of hair to be visible beneath the headscarf and knotting it under the chin. The caricature attempts to be inclusive and speak to a wide range of women, but only to a certain extent.

${ }^{6}$ On 28 December 2011, Turkish Air Forces killed 34 civilians misidentifying them for Kurdish rebels in Uludere, in the south-eastern part of Turkey, close to the border of Iraq. The BIA News Desk reported that 'Drones and thermal cameras identified a group of people heading for the border. F-16 planes took off and struck the group with missiles. With dawn, it was revealed that the group were not PKK members but young villagers who were trying to smuggle cheap gasoline over the border' (BLA News Desk, 2011). 
The humour is at the expense of Erdoğan and Gökçek who are demeaned by being represented as smaller than others, as children. Erdoğan even wears a t-shirt with what appears to be a teddy bear. As Medhurst and Desousa (1981: 214) suggest, the size of an object within the frame assigns its value and the caricaturists manipulate 'size as a part of the grammar of cartooning', to invite a particular depiction of politicians as having a 'diminutive stature'. Portraying Erdoğan and Gökçek in diminutive form is meant to suggest their lack of rationality. They are virtually little boys, in an adult world (see Medhurst and Desousa, 1981).

Bringing women together in solidarity, the caricature also acts as a reminder that it is women who bring men into the world, and it is women who deserve to decide what to do with their own bodies. In addition, it also suggests that it is important to have the right to abortion because it can prevent bringing into the world some who are better off not being born.

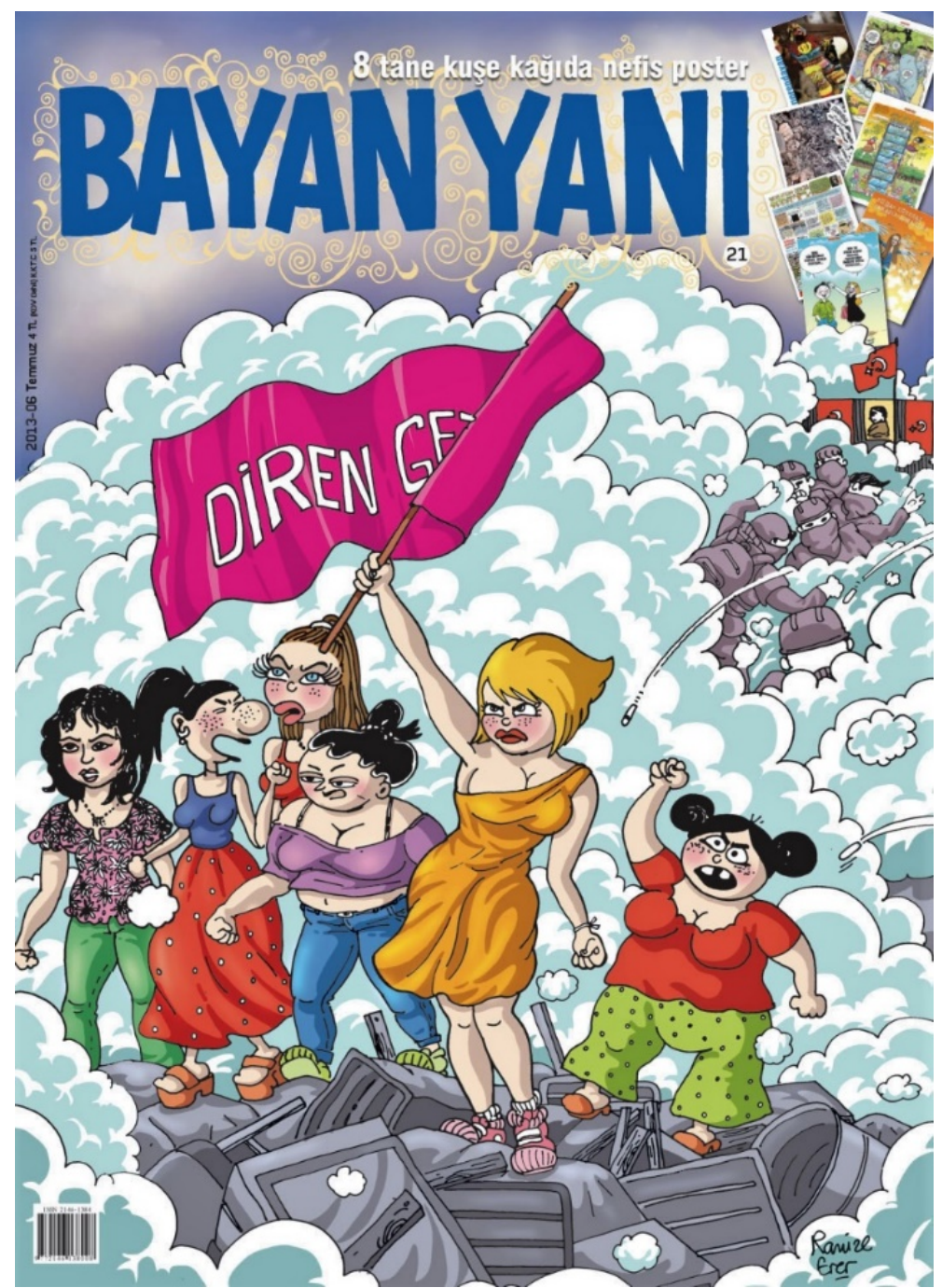

Figure 11. C Ramize Erer, Cover (Bayan Yanı, July 2013), (Reprinted with permission).

Caption:

RESIST GEZI

Figure 11 is another caricature related to the Gezi Park Protests, depicting famous characters from the magazine as protesters. The caricature is an interpretation of the famous painting 'Liberty Leading the People ( $\mathrm{La}$ Liberté Guidant le Peuple)' by French painter Eugène Delacroix. Witnessing the Paris uprising of July 1830, known as the 'Three Glorious Days', which was triggered by 'the liberal republicans for violation of the Constitution', Delacroix painted this famous work (Dorbani-Bouabdellah, 2009). In this sense, it can be claimed that the magazine associates the Gezi Park Protests with the Paris revolution of 1830, rather similar conditions led to each of the civil uprisings against authorities. In addition, it is also noteworthy that the caricaturist Ramize Erer, who is the creator of this caricature, has been living in Paris for years and is perhaps familiar with the painting and its historical background.

One of the symbols of the Taksim Square, Atatürk Cultural Centre, became a showcase for the protest banners, which can be seen in the top far right-hand corner of Figure 11, covered with national flags and a portrait of 
Atatürk, just like the placement of the Notre Dame Cathedral in Delacroix's painting. However, differing from the painting, the leading figure and the characters in the foreground are women and none of them carry any kind of weapon. In the background is second group of protestors (genders unclear) and police in conflict with one another. The latter are in black, wearing gas masks and helmets for protection but masking their identities. The protestors carry backpacks and cover their faces against tear gas with fabric (a common practice of the Gezi Park protesters). Similar to the painting, dust and smoke surround the figures and bullet-like objects fly over the protesters, just as tear gas and plastic bullets had in Gezi Park. In the Delacroix painting, the essence of victory is symbolized in 'a pyramidal composition; the base, strewn with corpses, resembles a pedestal supporting the image of the victors' (Dorbani-Bouabdellah, 2009). Figure 11 also presents a pyramidal structure but there are scrap materials under the protesters' feet that were commonly used as barricades during the protests.

The leading female caricature in Figure 11 wears a yellow, off-the-shoulder dress and waves a flag, just like the leading figure in Delacroix's painting, but in contrast to the painting the leading female character's breast is not visible and rather than the national flag, she is holding a bright pink flag, sporting the slogan 'RESIST GEZI' (DIREN GEZI), which was a common hashtag on social media in support of the protests. The choice of the colour pink on the flag is pertinent. Reclaimed by post-feminists, pink signifies an expression of femininity. The colour yellow is referred to as the colour of sunshine, symbolising optimism, dynamism and happiness (Jirousek, 1995; Robinson et al., 2015). In Figure 11, yellow symbolises the leading female character with bearing hope amongst the chaos. In fact, she is one of the rebellious characters from the magazine, ironically known as Berna, the bad girl' (Kötü Kız Berna). She is a freedom fighter and a lively, attractive woman, who has no tolerance for unfairness and inequality, as is also evident in this caricature.

The figure on the left side of leading female character is 'Afet, the life coach' (Yaşam Koģu Afet) and she is the wisest character in the magazine. Living in a rural area she always provides useful advice in a clever and witty way to other women around her. Here, she has her hair double knotted (as always), wears a red t-shirt showing her cleavage and bright green, baggy printed trousers that are similar to those worn by rural women in some parts of Turkey. These codes in Figure 11 place her as a representative of rural women. The first woman on the right-hand side of the leading female figure is another rebellious freedom fighter, known as Dilex. She lives in Istanbul and is a young, modern and slightly overweight woman demonstrating 'body positivity', which is shown in the caricature: she is not afraid of showing her body with all its imperfections and flaws. Next to her, there is the self-portrayal of İpek Özsüslü (the caricaturist). Sidıka, the house girl, stands to the right of her; she is a 20-year-old daughter of a working-class family who lives in the suburbs of Istanbul. In her social circle she is more interested in world affairs and environmental issues, adopting a utopian idealism of changing the whole world, starting with her family and close circle (Atalay, 2012). This explains why she is depicted at the heart of the protest. The last woman portrayed is Raziye İçoğlu (the writer), who usually appears alongside her magazine column. By depicting female characters with different features, interests and backgrounds the magazine communicates the possibility of empowerment for a relatively variety of women, suggesting any woman can be on the frontline resisting and fighting for various forms of injustice. However, it can also be argued that the variety represented here is quite limited, as many women living in Turkey are left out, such as, women with headscarves, women of colour or women with disabilities, even though the women protesters were quite diverse in many ways, in the Gezi Park protests.

\section{CONCLUSION}

This article has presented a selective, indicative analysis of the way in which certain forms of feminism have been constructed through the caricatures published in the Bayan Yam magazine from 2011 to the end of 2017. I began with briefly presenting the magazine, its ideology and appearance on the market as a feminist publication. Then, the methodological framework explained the image selection process and analytical framework of the article. By examining the visual and verbal aspects of sampled caricatures, the article offered an understanding of the major tendencies and shifting dynamics in the depiction of the key feminist trends within the magazine.

My analysis has shown that the role of the magazine was primarily a feminist activist response to an authoritarian anti-feminist regime in Turkey. This was either on the part of individuals or in solidarity, employing satirical, ironical, metaphorical and humorous representations of resistance. However, the magazine also reproduced various gendered roles and norms as an inevitable reality of humour (as has been argued by several scholars: Mackie, 1990; Holmes, 2006; Kotthoff, 2006). Nevertheless, it can be suggested that the magazine functions as an outlet for feminists and feminist ideas, with its caricatures that play a role in both reflecting and creating activism amongst women in Turkey. Furthermore, the magazine represents a diversity of women; however, it might be argued that there are some limitations to the diversity represented. From an intersectional perspective, there appears to be some degree of avoidance that is evident in very limited or sometimes non-existent representations 
of covered women or indeed Muslim feminists, lesbians, disabled women or women of colour, for example. This is an area for future potential research and clearly something that needs further investigation. Modern Turkey is a diverse society having a lively dialogue about feminism; some of that debate is enabled and stimulated in the realm of popular culture and specifically through comics. Comics have long been part of popular political debate in Turkey and have provided a framework for alternative discourses such as feminism to flourish, we are only just beginning to recognise how the public sphere might be enriched by such visual activism.

\section{REFERENCES}

Akyüz, H. (2014) Hz. Peygamber'in Hadislerinde Renklerin Dili, [Language of colours in His Holiness’ Hadiths], Atatürk Üniversitesi Ilahiyat Fakultesi Dergisi, 41, 373-397. Available at: http:/ / dergipark.gov.tr/download/articlefile/31212 (Accessed 10 March 2019).

Arat, Y. (2013). Gezi Parkı direnişi: Demokrasi açığı, demokrasi gücü, [Gezi Park resistance: Democracy gap, democracy power], Bilim Akademisi Dernĕgi, Available at: https://bilimakademisi.org/wpcontent/uploads/2013/08/Gezi-Parki-Direnisi_Demokrasi-Acigi-Demokrasi-Gucu.pdf (Accessed 3 November 2019).

Amnesty International. (2013). Gezi Park protests brutal denial of the right to peaceful assembly in Turkey, Amnesty International. Available at: https://www.amnesty.org/en/documents/EUR44/022/2013/en/ (Accessed 3 November 2019).

Atalay, A. (2012). Sidika. Atilla Atalay Yar Resmi Enternet Sitesi. Available at: http:/ / atibey.blogspot.com/p/sdka.html (Accessed 10 November 2018).

Bayan Yan1 (2016). Cover page, Bayan Yam. Author: Unknown, Issue no: 51, (March), p.1.

BLA News Desk. (2011). Turkish air strike kills more than 30 civilians, Bianet, Available at: https://bianet.org/english/human-rights/135084-turkish-air-strike-kills-more-than-30-civilians (Accessed 24 July 2019).

BLA News Desk. (2014). Erdoğan: Bringing men and women to equal status is against nature, Bianet. Available at: https:/ / m.bianet.org/english/women/160213-erdogan-bringing-men-and-women-to-equal-status-is-againstnature (Accessed: 18 January 2019).

BLA News Desk. (2015). Bülent Arınç: Be silent as a woman!, Bianet, Available at: http:/ / bianet.org/english/women/166434-bulent-arinc-be-silent-as-a-woman (Accessed 8 January 2019).

BLA News Desk. (2016). Attack against people opposing copper mine in Artvin, Bianet, Available at: https://bianet.org/english/environment/172159-attack-against-people-opposing-copper-mine-in-artvin (Accessed 8 May 2019).

Bilger, A. (2009). Comedy. In E. Kowaleski-Wallace, (ed.), Encyclopedia of Feminist Literary Theory (pp.119-121), London and New York: Routledge.

Cantek, L. (1997). Leman, Anti-Medya ve İç Savaş Manzaraları, [Leman, Anti-Media and Civil War Scenery]. Birikim Dergisi, 102, 61-76. Available at: http://www.birikimdergisi.com/birikim-yazi/5141/leman-anti-medya-ve-icsavas-manzaralari\#.WWZ_6emQzIU (Accessed 15 June 2017).

CNN Türk. (2015). Bayan Yanı'ndan özel sayı: "Kadınlar mizah da yapar beyler!", [Special Issue of Bayan Yanı: Women can make humour too, gentlemen!], CNN Türk, Available at: http:/ /www.cnnturk.com/haber/turkiye/bayan-yanindan-ozel-sayi-kadinlar-mizah-da-yapar-beyler (Accessed 9 May 2017).

Creed, B. (1993). The Monstrous-Feminine Film, Feminism, Psychoanalysis. London: Routledge.

Creed, B. (1999) Horror and the monstrous feminine: An imaginary abjection In S. Thornham. (ed.), Feminist Film Theory: A reader (pp.251-267), Edinburgh: Edinburgh University Press.

Dorbani-Bouabdellah, M. (2009). July 28: Liberty leading the people, Lowre Museum Official Website. Available at: https://www.louvre.fr/en/oeuvre-notices/july-28-liberty-leading-people?selection=44900 (Accessed 20 May 2019).

English, T. (2015). Rosie the Riveter's journey from propaganda to feminist icon. Does the history of an image matter?, The Humanities Index. Available at: https://humx.org/rosie-the-riveter-985cd6e3a8a4 (Accessed 26 March 2019).

Erer, R. (2012). Inside page, Bayan Yanı. Issue no: 12, (June), p. 3.

Erer, R. (2013). Cover page, Bayan Yanı. Issue no: 21, (July), p. 1.

Erer, R. (2015). Cover page, Bayan Yanı. Issue no: 44, (August), p. 1.

Girardot, C. (2017) Fueling Turkish feminism with satire and humour. Mashallab News, Available at: https://www.mashallahnews.com/fueling-turkish-feminism-with-satire-and-humour (Accessed 10 November 2018). 
Gray, F. (1994). Women and Laughter. London: Palgrave

Harrington, E. (2018). Women, Monstrosity and Horror Film: Gynaehorror. London: Routledge

Holmes, J. (2006). Sharing a laugh: Pragmatic aspects of humor and gender in the workplace. Journal of Pragmatics, $38(1), 26-50$.

Hürriyet Daily News. (2012). Abortion sparks raging debate in Turkey, Hürriyet Daily News. Available at: http://www.hurriyetdailynews.com/abortion-sparks-raging-debate-in-turkey-21740 (Accessed 11 January 2019).

Hürriyet Daily News. (2013). Presence of pregnant women in public is 'disgraceful,' says Turkish lawyer, Hürriyet Daily News. Available at: http://www.hurriyetdailynews.com/presence-of-pregnant-women-in-public-isdisgraceful-says-turkish-lawyer--51380 (Accessed 10 January 2019).

Jirousek, C. (1995). Art, Design and Visual Thinking An Interactive Textbook. Ithaca: Cornell University. Available at: http:// char.txa.cornell.edu/ (Accessed 22 October 2018).

Kimble, J. J. and Olson, L. C. (2006). Visual rhetoric representing Rosie the Riveter: Myth and misconception in J. Howard Miller's 'We Can Do It!' poster. Rhetoric \& Public Affairs, 9(4), 533-569. Available at: https://muse.jhu.edu/article/210135\#info_wrap (Accessed 1 April 2019).

Kotthoff, H. (2006) Gender and humor: The state of the art. Journal of Pragmatics, 38(1), 4-25.

Kress G. and van Leeuwen, T. (2006). Reading Images: The grammar of visual design. London: Routledge.

Lemish, D. and Muhlbauer, V. (2012). 'Can't have it all': Representations of older women in popular culture. Women \& Therapy, 35(3-4), 165-180.

Letsch, C. (2012). Turkish women join pro-choice rally as fears grow of abortion ban, The Guardian. Available at: https://www.theguardian.com/world/2012/jun/03/turkish-women-rally-abortion-ban (Accessed 12 January 2019).

Mackie, M. (1990). Who is laughing now? The role of humour in the social construction of gender. Atlantis, 15(2), 11-26. Available at: https://pdfs.semanticscholar.org/e49c/8b3b0bfe3e6c9f31268de2fbd07318ba0eab.pdf (Accessed 15 September 2019).

Medhurst, M. J. and Desousa, M. A. (1981). Political cartoons as rhetorical form: A taxonomy of graphic discourse. Communication Monographs, 48(3), 197-236.

Milkman, R. (1987). Gender, consciousness, and social change: Rethinking women's World War II experience. Contemporary Sociology, 16(1), 21-25. Available at: http://www.jstor.org/stable/2071182 (Accessed: 9 April 2019).

Milliyet. (2011) Voleybolcu kıza İETTT otobüsünde kısa şort dayağı, [Beating of a volleyball player girl on an IETT bus because of wearing shorts], Milliyet. Available at: http://www.milliyet.com.tr/voleybolcu-kiza-iettotobusunde-kisa-sort-dayagi-gundem-1424438/ (Accessed 1 December 2018).

Nowell, L. S., Norris, J. M., White, D. E., and Moules, N. J. (2017). Thematic analysis: Striving to meet the trustworthiness criteria. International Journal of Qualitative Methods, 16(1), 1-13.

NTV. (2017). Çizer Ramize Erer'e Fransa'dan "Yaratıcı Cesaret Ödülü", [The Creative Courage Award from France to Ramize Erer], NTV. Available at: https://www.ntv.com.tr/sanat/cizer-ramize-erere-fransadanyaratici-cesaret-odulu,pIS7u7nIL0-PPWmhekiWPA?_ref=infinite (Accessed 7 October 2018).

Özen, H. (2015). An unfinished grassroots populism: The Gezi Park protests in Turkey and their aftermath. South European Society and Politics, 20(4), 533-552.

Özsüslü, İ. (2011). Cover page, Bayan Yamı. Issue no: 6, (September), p. 1.

Özsüslü, İ. (2013). Inside page, Bayan Yamı. Issue no: 21, (July), p. 3.

Özsüslü, İ. (2013). Cover page, Bayan Yanı. Issue no: 22, (August), p. 1.

Özsüslü, İ. (2014). Inside page, Bayan Yam. Issue no: 31, (June), p. 3.

Özsüslü, İ. (2017). Cover page, Bayan Yanı. Issue no: 67, (August), p. 1.

Rees, E. L. E. (2013). The Vagina: A literary and cultural history. London and New York: Bloomsbury Academic.

Robinson, M. D., Liu, T. and Bair, J. L. (2015). Affect-related influences on color perception. In A. J. Elliot, M. D. Fairchild and A. Franklin. (eds.), Handbook of Color Psychology. (pp. 660-679). Cambridge: Cambridge University Press.

Rose, G. (2016). Visual Methodologies: An introduction to researching with visual materials. (4th Ed.) London: SAGE Publications.

Santana, M. C. (2016). From empowerment to domesticity: The case of Rosie the Riveter and the WWII campaign. Frontiers in Sociology, 1(16), 1-8.

Tekay, C. (2013). Part I: History of the woman question and feminism in Turkey. Talk Turkey Conference: Rethinking life since Geri, The New School's Historical Studies Department. Available at: http://www.jadaliyya.com/pages/index/15037/rethinking-gezi-through-feminist-and-lgbt-perspect (Accessed 10 May 2016).

The Nib. (2017). İpek Özsüslü, The Nib, Available at: https:/ / thenib.com/ipek-ozsuslu (Accessed 9 October 2018).

Tobias, S. (1997). Faces of Feminism: An activist's reflections on the women's movement. New York: Routledge. 
Toksabay, E. (2011). With satire, woman's magazine tackles taboos in Turkey. Reuters. Available at: https://www.reuters.com/article/us-turkey-women-magazine-idUSTRE76J5UR20110720 (Accessed 9 October 2018).

Tyler, I. (2011). Pregnant beauty: Maternal femininities under neoliberalism. In R. Gilland C. Scharff(eds.), New Femininities: Postfeminism, neoliberalism and subjectivity (pp.21-37). Basingstoke: Palgrave Macmillan.

Walker, B. G. (1983). The Women's Encyclopedia of Myths and Secrets. San Francisco: Harper \& Row.

Yalçınkaya, C. T. (2006). A Shift in the Tradition of Humour Magazines in Turkey: The case of L-Manyak and Lombak (MSc Thesis). Middle East Technical University. Available at: http://etd.lib.metu.edu.tr/upload/ 12608118/index.pdf (Accessed 2 March 2017).

Yılmaz, B. (2013). Inside page, Bayan Yam. Issue no: Special Issue, (March), p. 25.

Yılmaz, B. (2015). Inside page, Bayan Yanı. Issue no: 43, (July), p. 31.

Citation: Erkul, S. (2020). Activist Feminism in Turkey, Represented Through the Caricatures of Bayan Yan1 Magazine. Feminist Encounters: A Journal of Critical Studies in Culture and Politics, 4(1), 08. https://doi.org/10.20897/femenc/7912 